\title{
The Euratom Community Treaty's prospects at the start of the new millennium
}

\author{
Christiane Trüe \\ Institute for International Law, \\ University of Göttingen, \\ Platz der Göttinger Sieben 5, \\ Göttingen D-37073, Germany \\ E-mail: CTruee1@gwdg.de \\ Rechtsanwältin, \\ Volgersweg 4 A, \\ Hanover D-30419, Germany
}

\begin{abstract}
Which aspects of the Euratom Treaty might require reform in order to answer the challenges of the new Millennium? A call is made for the integration of the Euratom Treaty into a comprehensive European Union Treaty or Constitution encompassing all EU activities, making the promotion of nuclear technology a matter of enhanced cooperation, while preserving uniform radiation protection and safeguards standards. Provisions regarding nuclear safety and waste management standards should be added. Both enhanced cooperation and uniform standards should be guided by uniform constitutional principles, including democracy and the commitment to environmental protection. This would, on the one hand, preserve as much unity of EU and Euratom law as possible. On the other hand, it would allow Member States which have opted for the use of nuclear technology to pursue this within the common EU framework, and the others to terminate their involvement in the promotion of nuclear technology.
\end{abstract}

Keywords: Euratom; promotion of nuclear industries; legitimacy; democratic deficit; legislative; competences; internal market/state aids/competition rules; environmental; protection; enhanced cooperation.

Reference to this paper should be made as follows: Trüe, C. (2006) 'The Euratom Community Treaty's prospects at the start of the new millennium', Int. J. Nuclear Law, Vol. 1, No. 3, pp.247-260.

Biographical notes: Dr. Christiane Trüe LL.M. (East Anglia) joined the Institute for International Law, University of Goettingen, Germany, in May 2002 as a Senior Research Fellow, specialising in nuclear, energy and environmental law as well as European Union law (list of publications on www.user.gwdg.de/ ujvr/atom/ct.htm). Her PhD is on the subject of a 'System of Legislative Competences of the EU and the EC' (Goettingen, 2002). Previously, she held research and teaching posts in German, EU and international law at the University of East Anglia, UK, and at the German Universities of Marburg/Lahn and Goettingen. She has been a member of the German Bar (Rechtsanwältin) since 1996. 


\section{Introduction}

The Euratom Treaty has largely remained in its original 1957 state until today, ${ }^{1}$ whilst the EC Treaty and the EU Treaty have been amended several times and with many substantive changes and additions. Given that the situation of the nuclear industry has developed since 1957, and that circumstances have changed considerably since then, quite a few of the Euratom provisions are regarded as outdated, inadequate or obsolete, ${ }^{2}$ whilst other provisions are not included although there is a strong support, at least in some Member States or from some groups that they should be. ${ }^{3}$ Nonetheless, despite being intended to mark a new era of European integration in the new Millennium, the proposed 'Treaty establishing a Constitution for Europe' did not address any of these concerns. It excluded the Euratom Treaty from the process, leaving it on the sidelines, to be merely annexed to the 'Constitution for Europe' by the very last protocol, ${ }^{4}$ which was to make a few amendments to it. As the future of the Constitution appears rather uncertain at present, we will not concern ourselves with it in too much detail any more. With regard to the Euratom Treaty it did not change nor improve much. Amendments to the Constitution would have been necessary anyway, due to its many deficiencies, and thus also to cater for the specific problems of the nuclear sector appropriately. In what follows I shall concentrate on the most important substantive issues for reform of the Euratom.

\section{The Euratom Treaty - a fossil?}

Given its age and its largely unamended state the Euratom Treaty has often been called a fossil, particularly by those who wish to phase out nuclear technology for energy generation altogether. ${ }^{6}$ Others warn that its radiation protection and safeguards standards ${ }^{7}$ are as valuable as ever and must not be abolished, but, if anything, updated or extended. ${ }^{8}$ There are also some features that are open to more general criticisms, and where reform seems desirable, regardless of the position one takes towards nuclear technology. ${ }^{9}$ These include provisions which do not appear to meet today's requirements, such as

- the Treaty objective of promoting the 'speedy establishment and growth of nuclear industries'

- the existence of provisions which have never been applied as intended by the authors of the Treaty and

- Euratom's democratic deficit and ensuing lack of legitimacy,

and other provisions whose legal drafting is unclear or inconsistent with other EU law, resulting in

- uncertainty with regard to the scope of Euratom competences, their delimitation from the EC's competences on the one hand and from the Member States' competences on the other, including the lack of provisions or clear competences with regard to nuclear safety, that is, the safety of installations, decommissioning and waste management, 
- the inconsistency of the Euratom Treaty with EU Treaty and EC Treaty provisions and principles, in particular, the incompatibility with the establishment of a free energy market and the relevant provisions on state aids and subsidies,

- the lack of integration of environmental protection requirements,

- the opaque architecture of the EU and the Communities.

I will not be able to address all these issues in equal depth in this short paper, but will have to focus on a few points from this list.

\subsection{The treaty objective of promoting nuclear industries: a legitimacy problem}

Whatever the attitude towards the use of nuclear technology for the generation of energy, the Treaty objective of promoting nuclear industries would not be included in the same way in a Euratom Treaty drafted today, and by today's Member States. In the 1950s, nuclear industries in the (then) Member States, as elsewhere, were still in their infancy. This is not the case any more. The nuclear option may not, or not fully, have fulfilled its prospect of contributing to the raising of the standard of living in the Member States, but nuclear industries have been established in those Member States which decided in favour of this option. At the same time, a common nuclear industry of the Community never materialised: industries remained national. Indeed, a common nuclear industry seems now an even remoter possibility after the accession of several non-nuclear Member States, and the decision to phase out nuclear energy generation in a number of others, including Germany. Given the opposition to such industries from many European citizens it cannot be justified any more to make the aim of promoting nuclear industries, and the privileges attached to it, such as the provision of funding and a far-reaching exemption from market liberalisation, a binding matter for all Member States. After all, only three of the 'old' 15 member states have not taken a negative decision on the use of nuclear technology for energy generation; developments in the five new Member States who have nuclear power plants on their territories and appear to welcome them for the sake of energy supply relatively independent from foreign, particularly Russian, sources, remain to be seen. The legitimacy of spending considerable amounts of taxpayers' money ${ }^{10}$ on an industry many European citizens do not wish to support is questionable. The other treaty privileging a certain source of energy, the Coal and Steel Treaty, expired in 2002, and, from the point of view of democratic legitimacy, at least the privileges for nuclear industries should follow. ${ }^{11}$

However, it also remains to be seen whether the opposition to nuclear technology will remain as strong as it is at present, given that nuclear technology may actually contribute to mitigate climate change: nuclear power plants, once built, do not emit carbon dioxide. The Commission claims that a possible reduction of $7 \%$ in emissions by 2010 is achievable by the use of nuclear energy generation, and suggests that tackling climate change will become even more difficult without the nuclear option. ${ }^{12}$ In addition to the problems of climate change, technological progress may further improve nuclear safety, thus lessening public resistance against nuclear technology. 


\subsection{Euratom's democratic deficit}

The question of the continuing legitimacy of the aims of the Euratom Treaty takes me to the first major point of criticism, its democratic deficit. The Euratom Treaty has hardly been amended with regard to the position of the citizens' representative, the European Parliament, at least not with regard to the legislative process. ${ }^{13}$ The EP still only enjoys at best a right to be consulted on a proposed piece of secondary legislation; sometimes there is no obligatory participation of the EP at all. For example, with regard to external relations, the EP only has a say if the Commission voluntarily seeks its opinion. Consequently, legitimacy of secondary Euratom legislation is provided indirectly via the Council of Ministers, that is, the Member State governments, which, in turn, are controlled by the relevant Member State's parliament, with all the deficiencies attached to this process with regard to lack of information, majority voting, secrecy of Council proceedings and the need for compromise. The consultation of the EP may have an additional, but merely supplementary function in providing legitimacy. ${ }^{14}$

With regard to secondary legislation, legislating without EP participation or after its mere consultation has been considered more and more unacceptable for the EC, considering the depth of regulation and its impact on the individual citizen. ${ }^{15}$ The same would appear to apply to the Euratom, although there is one crucial difference: the Euratom Treaty deals with a very specific and technical area, far beyond the understanding of the ordinary citizen. As opposed to this, the EC Treaty is a framework treaty. As a rule, such a framework treaty cannot include provisions which would all be specific enough to make its secondary legislation sufficiently predictable to extend the legitimation stemming from ratification to each and every legislative act made under it. Thus, democratic legitimacy provided initially by ratification would be even weaker for the EC Treaty than for other, more specific international agreements such as the Euratom Treaty. However, this is not to say that democratic legitimacy with regard to the latter is satisfactory.

It is thus regrettable that the Euratom legislative procedure was omitted from the democratisation of the legislative process by the proposed EU Constitution: only with regard to the EC area the Constitution would have improved the situation by making the codecision procedure the regular legislative procedure for 'proper' legislative acts (and even here this was subject to numerous exceptions ${ }^{16}$ ). In the Euratom Treaty the legislative procedures prescribed by the individual legal bases were to remain the same (consultation or no participation of the EP). Thus, the codecision procedure would not have been extended to the Euratom area, although, nominally, the Constitution provisions on the legislative procedure were to apply to it as well (Article 3 Euratom Protocol). Accordingly, the Constitution would not have improved the democratic legitimacy of secondary legislation based upon the Euratom Treaty.

An additional problem with regard to democratic legitimacy arises from the process of ratification of the Treaty by Member State parliaments prior to its entering into force in 1958, and of the ratification of any accession and amendment treaties. Democratic legitimacy of the Euratom itself and its secondary legislation relies on this ratification, in particular due to the deficiencies of indirect legitimation via the Council. However, such ratification will often have been achieved by way of a package deal, as a price to be paid for EU membership or for progress in European integration in other areas, not due to the will to actively promote nuclear industries; this applies in particular to new non-nuclear Member States such as Austria. 
Here the failed Constitution would in fact have provided an instrument to ensure legitimacy of Euratom membership: it would have become possible to become or remain a Member State of the EU without being a Member State of the Euratom (Art. I-58 - I-60 Constitution/Art. 3 Euratom Protocol); those Member States that would choose to remain a Euratom Member would do so covered by the legitimation of their domestic parliaments. This remedy to the problem of legitimacy will be taken up again when considering enhanced cooperation as a solution.

Another legitimacy problem arises from the lack of transparency of Euratom law due to gaps, provisions deviating from practice or secondary law, etc., some of which will be explained in the following. The common problem of such lacks in transparency is that the citizens and their representatives in parliament can only legitimate what they can come to at least some basic understanding of, ${ }^{17}$ and, as will be shown, this is not always certain with regard to Euratom law.

\subsection{Competences: unclear delimitations, gaps and overlaps}

The legislative competences of the Euratom are not always clearly delimited from those of the Member States; in addition, there are gaps and overlaps with EC legal bases: such problems arise whenever several legal regimes apply simultaneously in the same area. ${ }^{18}$ Accordingly, Euratom competences have repeatedly given rise to litigation before the

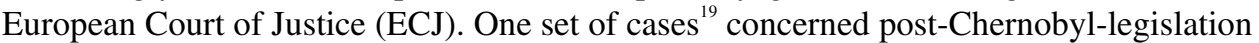
on contaminated food, regarding which there is an overlap of EC legislative competences for common commercial policy and the internal market on the one hand and the Euratom competence for radiation protection on the other: there the ECJ decided as to the 'correct' legal basis to be used on the basis of the 'centre of gravity' of the individual acts. In doing so it accepted that, generally, EC legal bases could apply in the area of Euratom law as long as the relevant Euratom provisions were not conclusive. What is striking about these cases is that the substance of the legislative acts concerned was nearly the same, but the result found as to the correct legal basis, mainly grounded on the objectives of the acts, varied. Thus, there is not much legal certainty as to which of several relevant legal bases to apply at present. The post-Chernobyl-case between the EP and the Council also illustrated the democratic deficit of the Euratom discussed previously, as the relevant difference between the legal bases was the amount of influence accorded to the European Parliament and each Member State in the legislative procedure. $^{20}$

Secondly, with regard to the delimitation of Euratom and Member State competences it must be noted that the regulatory competences of the Euratom are restricted in scope, that is, largely to radiation protection and safeguards. Thus the Euratom competences have often been construed broadly to avoid gaps in the competences system ${ }^{21}$ however, not all Member States have always immediately accepted this. The ECJ first had to decide how far Euratom competences were affected by the 1979 IAEA Convention on the Physical Protection of Nuclear Material, Facilities and Transports. ${ }^{22}$ The ECJ ${ }^{23}$ held that, under the Euratom Treaty, the Member States could only participate in the Convention subject to the condition that the Euratom was a party to the latter on the same lines as the Member States in so far as its own powers and jurisdiction are concerned; the powers concerned were "no fewer than four individual chapters of the treaty', namely the chapters relating to supplies, the nuclear common market, safeguards and property ownership. Similarly, in a more recent case ${ }^{24}$ the ECJ was called upon to 
decide to what extent the Euratom should be a party to the IAEA's Nuclear Safety Convention, in particular, whether the Euratom's legislative competence for radiation protection extended into the area of nuclear safety of installations, which is otherwise left to the Member States. The ECJ held that Euratom's radiation protection competence does extend into the area of nuclear safety, as effective radiation protection required addressing the possible sources of radiation, however, the exact extension of the radiation protection legal basis into the area of nuclear safety remained open. ${ }^{25}$

The underlying problem is that, as the Euratom Treaty does not include any explicit legal basis with regard to nuclear safety, secondary legislation in this area can only be made as an adjunct to activities in related areas, in particular, radiation protection, research and investment. ${ }^{26}$ Accordingly, the Euratom research programmes have included safety issues from the beginning, ${ }^{27}$ and the Euratom engaged in considerable activities to improve the safety of nuclear installations in the Middle and Eastern European and CIS states, in particular, by providing financial support for the upgrading of safety of nuclear power stations. ${ }^{28}$ However, the attempts by the Commission to implement the Nuclear Safety Convention by introducing a Directive on nuclear safety as part of its 'Nuclear Package' have so far failed. ${ }^{29}$ This raises particular problems with regard to international agreements, which, like the IAEA Conventions mentioned above, must be concluded as 'mixed agreements', with the Euratom and its Member States being parties to the agreement at the same time. In particular, this may result in an inability to use the advantages EU law has over public international law with regard to its binding force and mechanisms of enforcement.

Given the importance of nuclear safety of installations (and equally: waste management, decommissioning and transport) for public health, both in nuclear and in non-nuclear states, clarification of responsibilities would be highly desirable to ensure effective protection. However, the Constitution would not have done much to improve the system of competences within the EU. The Euratom legal bases were left out altogether; the Constitution did not clarify their scope, nor did it close any of the gaps identified above. Instead, in its Article III-256 the Constitution provided for the introduction of yet another legal basis, a specific one for the energy sector. The latter, however, did not do much more than authorise the previous application of other, more general legal bases (such as Article 95, the legal basis for internal market legislation) to the energy sector, and would have created even more overlaps between legal bases in the energy sector. ${ }^{30}$

\subsection{Inconsistencies with principles of EU and EC law: internal market, state aids, competition rules}

The Euratom Treaty does not include any provisions on competition or subsidies which would correspond to Articles $81 / 82$ and 86 et seq. EC, and it is contested whether such rules have been omitted on purpose, thus excluding any application of the said EC rules ${ }^{31}$ or whether there is scope for their application. ${ }^{32}$ If not, the privileges granted to the nuclear industries under the Euratom Treaty appear incompatible with one of the EC principal objectives, the internal market, and in particular with a liberalised EU electricity market. Production costs of nuclear energy may presently be lowered by loans, subsidies and by exemptions from the competition rules which other electricity producers have to comply with. This may lead to distortions of competition in the internal 
electricity market. ${ }^{33}$ Unlimited subsidies grant nuclear technology an unfair advantage over other, non-subsidised sources, or may lead to the introduction of further subsidies or other privileges for other technologies which may be justified, for example, by environmental protection concerns (renewables). ${ }^{34}$ The electricity market would thus not be regulated by market mechanisms, but by privileges at the taxpayers' or the consumers' expense.

The position as regards EC subsidies law will be considered first: Article 87 (1) EC prohibits subsidies as a matter of principle, although it provides for various exceptions, subject to Commission scrutiny. An argument against the application of EC subsidies law to the nuclear sector can be made on the basis of the historic aims of the Euratom Treaty and its specific provisions on investment in nuclear technology (Articles 2 lit. c, 40 et seq., 173 et seq.). Indeed, in the past the 'speedy establishment and growth of nuclear industries' was furthered by considerable subsidies, both by the Euratom and by the Member States. ${ }^{35}$ On the other hand, the historic aims of the Treaties are not usually considered in their interpretation. Moreover, even if one wanted to rely on the historic aims, with regard to the subsidies rules the latter do not provide an entirely clear result: the Member States, as opposed to the Euratom, are not under any obligation to provide subsidies ${ }^{36}$ and the specific Euratom Treaty provisions were understood as only contemplating funding of research and investments in the initial period, but not thereafter. ${ }^{37}$ In any case, the specific Euratom provisions do not extend to a general privilege of nuclear industries over other forms of energy. In addition, the Euratom Treaty is not as such 'dirigiste', ${ }^{38}$ but also relies on market mechanisms, for example, with regard to the determination of prices (as a result of supply against demand, Article 67). ${ }^{39}$ Thus, apart from the specifically regulated areas of Euratom research and investment funding, the application of the EC subsidies provisions is not excluded by specific provisions of the Euratom Treaty. ${ }^{40}$ There are further arguments in favour of applying EC subsidies law to nuclear industries, which must be omitted here for lack of space.

Overall, given the political background, and the general principles of EC law which should be of general application, the legal situation on subsidies should be clarified de lege ferenda in a future consolidated EU Treaty or Constitution incorporating the Euratom Treaty. Consistency in free market principles should apply, and the nuclear industries should be strong enough by now to survive under market conditions, or perish just like other competitors in the energy market whose performance cannot survive under market conditions.

Turning to EC competition rules, the position here is somewhat different. As far as chapter VI Euratom Treaty on supply of ores, source materials and special fissile materials makes specific provisions, these take precedence over EC competition law. Apart from this core area with regard only to certain listed materials, the Euratom Treaty leaves space for the application of EC competition rules. ${ }^{41}$ Nevertheless, the Supply Agency (Article 53) in its format and with its privileges provided for by the Treaty is sometimes regarded as a superfluous restraint of competition. ${ }^{42}$ The Supply Agency was granted a monopoly under Commission surveillance to balance the supply and demand and to make sure that scarce material was distributed without discrimination. However, the Supply Agency never had to resort to its specific powers, and instead a simplified procedure was introduced. ${ }^{43}$ Thus, the law as it appears to the citizen is not what applies in practice, making this area untransparent, with the ensuing legitimacy problems explained earlier. 
At the same time, though, the Euratom Treaty appears to include provisions which amount to even more stringent internal market rules than those of the EC Treaty, allowing for only few specific exceptions from the non-discrimination rule. Thus Article 93 provides for the abolition of customs duties and quantitative restrictions in respect to specialised materials and equipment (listed in Annex IV) required by the nuclear industries; the separate internal market rules for the listed nuclear sector goods was justified by the Treaty aim to advance more quickly than with the EC common market. Still, with regard to materials not listed in Annex IV Article 28/30 EC would apply. ${ }^{44}$

However, a separate regime of free movement of goods specific to the nuclear sector does not appear necessary any more, and should be done away with de lege ferenda. Practice does not appear fully consistent with the ostensibly strictly separate regime of the nuclear common market anyway: Art. 28/30 EC and the legal bases for the establishment of the internal market and for common commercial policy were applied to materials for the nuclear industries, whether listed or not. For example, the dual use regulations ${ }^{45}$ include such goods although they are based only on the EC Treaty. ${ }^{46}$ Similarly, even the $\mathrm{ECJ}^{47}$ included nuclear sector goods into the general EC common commercial policy regime in its WTO opinion, where it held that the Euratom Treaty did not contain any provisions relating to external trade and that there was nothing to prevent agreements concluded pursuant to Article 113 (now 133) of the EC Treaty from extending to international trade in Euratom products. Moreover, the lack of clarity as to whether specific rules of the Euratom Treaty apply (only to be established after consultation of the annexes), and the fact that EC rules apply to all non-listed goods relevant to the nuclear sector anyway calls for a consolidated regime for all goods. This could be supplemented with the radiation protection and safeguards rules catering for the specific dangers of the nuclear industries, thus permitting additional exceptions (e.g. with regard to waste to be deposited within the Member State of its origin in order to avoid additional risks of long distance transports, etc.). This applies equally to free movement of workers and capital as well as the free provision of services, which are guaranteed specifically for the nuclear sector. Apart from the aim of speeding up the implementation of these freedoms for the sake of a speedy establishment of nuclear industries ${ }^{48}$ the provisions of the EC Treaty just appear to have been duplicated, and secondary legislation often applies to persons in the nuclear sector, too.

\subsection{Principles of EU and EC law: protection of the environment}

Neither the (then) EEC Treaty nor the Euratom Treaty included any provision on the protection of the environment at the time of their enactment (1958). However, whilst such a provision was incorporated into the EC Treaty in the mid-1980s with the Single European Act, the Euratom Treaty still only aims for the protection of the health of workers and the general public against the dangers of ionising radiation. Art. $6 \mathrm{EC}$ is not applicable to the Euratom. Whilst one might argue that, in the densely populated areas of Western Europe, this does not make much of a difference as the protection of the population and of the environment are inseparable (cf. Article 35 et seq. in the radiation protection chapter, which provide for continuous monitoring of the level of radioactivity in the air, water and soill ${ }^{49}$ ), this must be read in conjunction with the aims of the Euratom and thus marks a different, purely anthropocentric approach. ${ }^{50}$ Here, Article 184 on the separate legal personality of the Euratom, together with the explicit wording of Article 6 
EC and the principle of attributed competences, prohibits the otherwise very sensible extension of Euratom legal bases to environmental protection: They cannot be extended beyond their scope for the pursuit of an aim which is not one of the Euratom Treaty. ${ }^{51}$

The lack of such a legal basis does not appear politically acceptable any more, nor does it mirror today's approach to environmental protection, as was illustrated by the Commission's 'Nuclear Package' recently, in the reasoning of which the Commission often referred to the aim of environmental protection although it was acting solely on the basis of the Euratom Treaty and would thus not have the competence to consider the environment as such. ${ }^{52}$ The Constitution, or the 36th Protocol to it, would not have changed this situation.

\section{A possible solution: enhanced cooperation in the promotion of nuclear technology and uniform standards}

Given the legitimacy problems of the Euratom Treaty mentioned earlier it is suggested that it might be preferable to move the part of the Euratom Treaty relating to the promotion of nuclear technology into a new form of enhanced cooperation. ${ }^{53}$ Under the current Treaties, enhanced (or: closer) cooperation means that Member States who are willing to proceed faster that the others with EU integration establish a cooperation between themselves within the framework of the Treaty (Article $43 \mathrm{EU}$ and Article 11 EC). They can work together within the areas of the EC Treaty which are not subject to an exclusive EC competence, using the institutions, procedures and mechanisms of the EU, subject to all the relevant provisions of the EC and EU Treaties. Currently, the main fields of enhanced cooperation (though regulated specifically in the Treaty itself) are the monetary union with the Euro and the Area of Freedom, Security and Justice, where exceptions were granted to Denmark and the UK (Protocol on the Schengen acquis); the Euratom Treaty does not provide for enhanced cooperation at all so far. The most important limit to enhanced cooperation is currently that it may only be used for furthering the objectives of the EU, and that the acquis communautaire must be respected. Consequently, under the present Treaties enhanced cooperation cannot be established to allow Member States to step back from integration in an area they wish to reclaim for the ambit of their national competences. However, given that the increasing number of Member States requires some additional flexibility in order to keep all Member States committed to the core of European integration, such an option should be included in an amended EU Treaty or Constitution. The Euratom Treaty would be a particularly suitable case for this.

If such an opening was achieved, enhanced cooperation could offer a solution to some of the problems, in particular, the transparency and legitimacy problems mentioned above. This would open the option of pursuing the promotion of nuclear technology as a matter of enhanced cooperation within the common EU framework, but limited to those Member States which are still in favour of this option, and can thus legitimate expenditure and activities in pursuit of this objective. For these pro-nuclear states, enhanced cooperation would allow them to bring the Euratom Treaty provisions up to the new Millennium's requirements; Member States which oppose the nuclear option would not block this any more. These other Member States would be given the chance to terminate their involvement in the promotion of nuclear technology, in line with the will of the majority of their people. 
Nevertheless, the promotion of common safety and radiation protection standards remains an overriding priority to all EU Member States, as these are in the common interest of all. Consequently, all Member States should have a say in the decision on these standards. Radiation protection and safeguards standards should thus form part of the provisions of a consolidated EU Treaty or Constitution which are uniformly binding on all Member States.

In addition, both radiation protection and safeguards standards and any activities for the promotion of nuclear industries - pursued in enhanced cooperation - should be guided by uniform constitutional principles, such as legislative procedures in their most democratic form, internal market rules on competition and subsidies and environmental protection commitments. Exceptions to this rule should require justification and be explicitly provided for in the Treaty for the sake of clarity.

\section{Conclusions: guidelines for a consolidated treaty or constitution}

It will have become apparent from the above how far activities under the Euratom Treaty are interwoven with those under the EC Treaty, and that the EU Treaty amalgamates the existing treaties, as well as the secondary legislation made under them, to a considerable extent already. The EU and the Communities share the same institutions, and the EU Treaty calls for consistency of all activities. Many principles are, or should be, common to all three Treaties. The Euratom Treaty should thus be integrated into a consolidated Treaty or Constitution for Europe, with the option of pursuing the promotion of nuclear technology as a matter of enhanced cooperation, while, at the same time, preserving uniform radiation protection and safeguards standards. Both promotion and standards should be guided by uniform constitutional principles (democracy, internal market rules and environmental protection). In a uniform document it should also be easier to avoid or iron out the inconsistencies between the Treaties outlined above.

In addition, the quality of legal drafting should be improved: the legal bases of competence should be clarified with regard to their scope, and, where necessary, be extended. Other provisions obscuring what actually applies in practice should be updated. Provisions which have been duplicated before should be consolidated so as to apply to all relevant areas, thus enhancing transparency. All these provisions should be encompassed in a consistent energy chapter of a consolidated new Treaty or Constitution. Where necessary, this chapter should also cater for any specific regulatory needs of each form of energy. ${ }^{54}$

\section{Notes}

${ }^{1}$ With a list of the most important amendments Grunwald, Jürgen, Neuere Entwicklungen des Euratom-Rechts, 1 Zeitschrift für Europarechtliche Studien (1998) 275 at 277 note 6.

${ }^{2}$ For example, Scott, Joanne, Nuclear Health and Safety, 5 RECIEL (1996) 225; Hancher, Leigh, 53 MLR (1990) 669 at 572; Grunwald, Der Euratom-Vertrag: nie war er so wertvoll wie heute, 11 Europäische Zeitschrift für Wirtschaftsrecht (2000) 418; Cusack, Thomas F., A Tale of Two Treaties, 40 CMLR (2003) 117 at 121.

${ }^{3} \mathrm{Cf}$. the recent 'Nuclear Package' of the Commission, Available at: http://europa.eu.int/comm/ energy/nuclear/pdf/safety/dir_surete_en.pdf and http://europa.eu.int/comm/energy/ nuclear/ 
pdf/safety/dir_dechets_en.pdf (first draft), http://europa.eu.int/comm/energy/nuclear/2003/ 2003-01-30-acte_en.pdf (formal proposal), and COM (2004) 526, http://europa.eu.int/comm/ energy/nuclear/safety/doc/com_2004_0526_en.pdf (amended proposals of 8 September 2004). Also Trüe, Christiane, Legislative Competences of the Euratom Community and the EC in the Energy Sector: the Nuclear Package of the Commission, 28 ELR (2003) 664 at 675 et seq.

${ }^{4} 36$ th Protocol to the Constitution, amending the Treaty establishing the Euratom, OJ 2004, C 310, protocol C 310/391. The Constitution (including the Protocols) is available at: http://europa.eu.int/eur-lex/lex/en/treaties/dat/12004V/htm/12004V.html.

${ }^{5}$ In detail on the Protocol and on the new energy chapter Trüe, Christiane, EU-Kompetenzen für Energierecht, Gesundheitsschutz und Umweltschutz nach dem Verfassungsentwurf, 59 Juristenzeitung (2004) 779.

${ }^{6} \mathrm{Cf}$. Köhne, Anja, Preface, in: Clegg/Moreira da Silva/Turmes/Rothe (MEPs), Euratom Conference 'After 45 Years of Nuclear Promotion', available at: http://www.foeeurope.org/publications/ 2003/Euratom_proceedings_Nov_2002.pdf, p.5.

${ }^{7}$ The term 'safeguards' means the set of measures performed to verify that nuclear material and equipment are not diverted from their declared usage, Article 77 Euratom, cf. Hancher, 53 MLR (1990) 669 at 573.

${ }^{8}$ Trüe, 28 ELR (2003) 664 at 685; Scott, 5 RECIEL (1996) 225 at 229; Moulin, Andreas, Possibilities to Phase Out or Reform Euratom, in: Clegg/Moreira da Silva/Turmes/Rothe (MEPs) (note 6) p.51 et seq.

${ }^{9} \mathrm{Cf}$. also Contribution 121 to the European Convention from Mr Klaus Hänsch, Member of the Convention: 'Future of the Euratom Treaty', CONV 344/02, 14 October 2002, p.3-4, available at: http://register.consilium.eu.int/pdf/en/02/cv00/00344en2.pdf.

${ }^{10} \mathrm{Cf}$. Commeau-Yannoussis, Nina (DG TREN, European Commission), Do we still need a Euratom Treaty? In: Clegg/Moreira da Silva/Turmes/Rothe (MEPs) (note 6) p.55 at 56: 1.23 billion EUR budget for Euratom Research Framework Programme 2002-2006.

${ }^{11}$ Cf. Rocholl, Martin, Opening Remarks, in: Clegg/Moreira da Silva/Turmes/Rothe (MEPs) (note 6) p.8-9; Deleuze, Olivier, Euratom in an Open Energy Market, in: Clegg/Moreira da Silva/Turmes/Rothe (MEPs) (note 6) p.26; Molin, in: Clegg/Moreira da Silva/Turmes/Rothe (MEPs) (note 6) p.51 at 54.

${ }^{12}$ Commission Green Paper 'Towards a European Strategy for the Security of Energy Supply', COM (2000) 769 final; also Commeau-Yannoussis, in: Clegg/Moreira da Silva/Turmes/Rothe (MEPs) (note 6) p.55. Similar for example Patrick Moore, co-founder of Greenpeace, in: Miami Herald, 28 January, 2005, available at: http://www.greenspirit.com/logbook.cfm? msid=83, cf. also Patrick Moore, Nuclear Statement to the Congressional Committee, available at: http://www.greenspirit.com/logbook.cfm?msid=70.

${ }^{13}$ However, the EP has been granted the right to institute a committee of inquiry in order to investigate alleged contraventions or maladministration in the implementation of Union law, cf. Article 107b Euratom; still on the previous situation Hancher, 53 MLR (1990) 669.

${ }^{14} \mathrm{Cf}$. the German Federal Constitutional Court in its Maastricht decision, Collection of Cases Vol. 89, p.155.

${ }^{15}$ In detail on the provision of democratic legitimacy Trüe, Christiane, The Plurality of the Legislative Process and a System for Attributing Procedures to Competences, 6 German Law Journal (2005), Special Issue November, Available at: http://www.germanlawjournal.com.

${ }^{16}$ In detail Trüe, Christiane, Das System der EU-Komptenzen vor und nach dem Entwurf eines Europäischen Verfassungsvertrags, 64 HJIL (2004) 391 and 59 Juristenzeitung (2004) 779.

${ }^{17} \mathrm{Cf}$. Tuts, Geneviève, La Convention: plus de clarté, de transparence, d'efficacité et de démocratie pour l'Europe, 49 Revue de la Faculté de droit de Liège (2004) 341 at 346/356.

${ }^{18}$ In detail on the different positions with regard to the relationship between the Treaties and the availability of EC legal bases in the Euratom sector Trüe, 28 ELR (2003) 664 at 665/669 et seq.; Pechstein, Matthias, Elektrizitätsbinnenmarkt und Beihilfenkontrolle im 
Anwendungsbereich des Euratom-Vertrags, 12 Europäische Zeitschrift für Wirtschaftsrecht (2001) 307 at 309; Schroeder, Werner, Die Euratom - auf dem Weg zu einer Umweltgemeinschaft, Deutsches Verwaltungsblatt 110 (1995) 322 at 323; Pernice, Ingolf, EG-rechtliche Rahmenbedingungen der Atomrechtsreform, 5 Europäische Zeitung für Wirtschaftsrecht (1993) 497.

${ }^{19}$ C-62/88 - Hellenic Republic/Council [1990] ECR I-1527; C-70/88 Parliament/Council [1991] ECR I-4529.

${ }^{20}$ Which was cooperation of the Council with the EP at the time under Article 100 a (now 95) EEC Treaty and consultation under Article 130s (now 175) EEC Treaty, now upgraded to co-decision, as opposed to no participation under Article 113 (now 133) EEC Treaty. In addition, Article 130s EEC Treaty required unanimity in the Council at the time and the other legal bases only a qualified majority.

${ }^{21}$ With regard to radiation protection, EP in: C-70/88, EP/Council (Chernobyl II) [1991] ECR I-4529 at 4533. In detail Zuleeg, Manfred, Vorbehaltene Kompetenzen der Mitgliedstaaten der Europäischen Gemeinschaft auf dem Gebiete des Umweltschutzes, 8 Neue Zweitschrift für Verwaltungsrecht (1987) 280 at 285; Schröder, Meinhard, Grundsatzfragen des Lebensmittelschutzes im Falle anormaler radiologischer Ereignisse nach EWG- und Euratomrecht, in: Gedächtnisschrift für Wilhelm Karl Geck (1989) 753 at 756 et seq.; Grunwald, Jürgen, Tschernobyl und das Gemeinschaftsrecht, Europarecht (1986) 315 at 320 et seq., more recently Trüe, 28 ELR (2003) 664 at 668 et seq.; Scott, 5 RECIEL (1996) 225 at 225-6.

${ }^{22}$ IAEA Legal Series No. 12, Vienna 1982, Available at: http://www.iaea.org/Publications/ Documents/Infcircs/Others/inf274r1.shtml.

${ }^{23}$ ECJ Ruling 1/78 - Draft Convention of the IAEA on the Physical Protection of Nuclear Materials, Facilities and Transports [1978] ECR 2151 para. 6, 12 et seq.

${ }^{24}$ ECJ C-29/99 - Commission/Council [2002] ECR I-11221.

${ }^{25}$ In detail Trüe, 28 ELR (2003) 664 at 673-5. Cf. also Cusack, 40 CMLR (2003) 117 at 122, who regards nuclear safety as a narrower concept than radiation protection, and appears to regard the former as fully included in the latter.

${ }^{26}$ Alternatively, legislation in areas not covered as such by the Euratom Treaty may be based on the Euratom 'flexibility clause' (Article 203), that is, the legal basis for measures to attain Euratom objectives in the absence of any specific legal basis; this, however, requires unanimity in the Council.

${ }^{27}$ Currently Council decision 2002/668/Euratom concerning the sixth framework programme of the European Atomic Energy Community (Euratom) for nuclear research and training activities, also contributing to the creation of the European Research Area (2002-2006), Art. 1 (2) 4th indent, Annex I No. 3.1, OJ 2002 L 232/34. In detail Grunwald, Energierecht der Europäischen Gemeinschaften (2003), 288-90.

${ }^{28}$ Considerable funds were provided via the TACIS and PHARE programmes and via Euratom loans, cf. for further references Grunwald, Energierecht der Europäischen Gemeinschaften, 289-90; Benoit, P.L., L'union européenne et les risques nucléaire civil des pays de l'est, Revue du Marché Commun (1998) 253 at 257 et seq.

${ }^{29} \mathrm{Cf}$. the recent 'Nuclear Package' of the Commission (note 3). On the 'Nuclear Package' in detail Trüe, 28 ELR (2003) 664 at 675/681 et seq., cf. also Koutrakos, Panis, 41 CMLR (2004) 191.

${ }^{30}$ In detail Trüe, 28 ELR (2003) 664 at 669 et seq.; Trüe, 59 Juristenzeitung (2004) 779. Cf. also Rashbrooke, Gwenaele, Clarification or Complication? The New Energy Title in the Draft Constitution for Europe, 22 Journal of Energy and Natural Resources Law (2004) 373 at 380 et seq.

${ }^{31}$ In this vein Cusack, 40 CMLR (2003) 117 at 118/130 et seq.

${ }^{32}$ On the variance within the Commission with regard to EC subsidies law Financial Times Deutschland, 13 November 2000, p.14. With further references Pechstein, 12 Europäische Zeitschrift für Wirtschaftsrecht (2001) 307 et seq.; Schroeder, Deutsches Verwaltungsblatt 110 (1995) 322-3. 
${ }^{33}$ For details see Commission Communication 'Nuclear Safety in the European Union', COM (2002) 605 final, also Available at: http://europa.eu.int/comm/energy/nuclear/pdf/safety/ communication_en.pdf, No. 5, p.4; Regarding the Electricity Market Directive Report A5-0077/2002 of 12/03/02 (MEPs Turmes and Rapkay), amendment 68. Also Pechstein, 12 Europäische Zeitschrift für Wirtschaftsrecht (2001) 307 et seq.; Slot, Piet Jan, Energy and Competition, CMLR (1994) 511 at 538.

${ }^{34}$ Germany offers a good example for the promotion of renewable energy sources.

${ }^{35}$ For details see Grunwald, Energierecht der Europäischen Gemeinschaften, 229 et seq., 234 et seq.; Cusack, 40 CMLR (2003) 117 at 118/130 et seq.

${ }^{36}$ Pernice, 5 Europäische Zeitung für Wirtschaftsrecht (1993) 497 at 498.

${ }^{37}$ Hancher, 53 MLR (1990) 669 at 572.

${ }^{38}$ However, in this vein Cusack, 40 CMLR (2003) 117 at 125

${ }^{39}$ Also Pechstein, 12 Europäische Zeitschrift für Wirtschaftsrecht (2001) 307 at 310.

${ }^{40}$ Differenciating even further between research (permitted) and investment subsidies (subject to Art. 86 et seq. EC) Pechstein, 12 Europäische Zeitschrift für Wirtschaftsrecht (2001) 307 at 310-11; Fouquet, Dörte/von Uexküll, Ole, Der Beihilfecharakter der steuerlichen Freistellung von Rückstellungen der deutschen Atomindustrie, 7 Zeitschrift für Neues Energierecht (2003) 310; Hermes, Georg, Rückstellungen für die Entsorgung und Stillegung von Kernkraftwerken und EG-Beihilfenrecht, 3 Zeitschrift für Neues Energierecht (1999) 156. With regard to these areas also Cusack, 40 CMLR (2003) 117 at 134.

${ }^{41}$ Commission, decision 76/248/EEC (United Reprocessors), OJ 1976 L 51/7, more recently decision 91/329/EEC (Scottish Nuclear), OJ L 1991 178/31. Also Grunwald, Energierecht der Europäischen Gemeinschaften, 238; Cusack, 40 CMLR (2003) 117 at 134 et seq.

${ }^{42} \mathrm{Cf}$. O'Driscoll, Mervyn, What is Euratom and how does it work? In: Clegg/Moreira da Silva/Turmes/Rothe (MEPs) (note 6) p.10 at 21.

${ }^{43}$ EAEC Supply Agency: Rules of the Supply Agency of the European Atomic Energy Community determining the manner in which demand is to be balanced against the supply of ores, source materials and special fissile materials, OJ 1960 No. 32/777, amended by Regulation of the Supply Agency of the European Atomic Energy Community amending the rules of the Supply Agency of 5 May 1960 determining the manner in which demand is to be balanced against the supply of ores, source materials and special fissile materials, OJ 1975 L 193/37.

${ }^{44}$ Schroeder, Deutsches Verwaltungsblatt 110 (1995) 322 at 327.

${ }^{45}$ Currently Regulation (EC) No. 149/2003 amending and updating Regulation (EC) No.1334/2000 setting up a Community regime for the control of exports of dual-use items and technology, OJ 2003 L 30/1.

${ }^{46} \mathrm{Cf}$. on this issue Grunwald, Energierecht der Europäischen Gemeinschaften, 272.

${ }^{47}$ ECJ opinion 1/94 - WTO [1994] ECR I-5267 No. 24. On the external relations of Euratom Grunwald, Energierecht der Europäischen Gemeinschaften, 277 et seq.

${ }^{48} \mathrm{Cf}$. Grunwald, Energierecht der Europäischen Gemeinschaften, 273-4.

${ }^{49}$ Cf. Cusack, 40 CMLR (2003) 117 at 122.

${ }^{50}$ Also Scott, 5 RECIEL (1996) 225.

${ }^{51}$ With further references Trüe, 28 ELR (2003) 664 at 681 et seq. Also Hancher, Leigh, Energy and the Environment: Striking a Balance? 26 CMLR (1989) 475 at 486-7.

${ }^{52}$ Nuclear Package (note 3), Commission Memorandum of 6 November 2002 'Towards a Community Approach to Nuclear Safety', Available at: http://europa.eu.int/comm/ energy/nuclear/pdf/new_package/memo_en.pdf; in detail Trüe, 28 ELR (2003) 664 at 681 et seq.

${ }^{53}$ Trüe, 59 Juristenzeitung (2004) 779 at 783. 
${ }^{54} \mathrm{Cf}$. previous proposals to this end by the Commission, Report from the Commission to the Council on Civil Protection, Tourism and Energy, SEC 1996496 final, available at: http://aei.pitt.edu/archive/00003938/01/000135_1.pdf and White Paper 'An Energy Policy for the European Union', COM (1995) 682 final, p.38; by the EP, Parliament resolution incorporating its opinion on the convening of the Intergovernmental Conference and on evaluation of the work of the Reflection Group and definition of the political priorities of the European Parliament with a view to the Intergovernmental Conference, 13 March 1996, Bulletin EU 3-1996 No. 15.1; also Contribution 121 to the European Convention from Mr Klaus Hänsch, Member of the Convention: 'Future of the Euratom Treaty', CONV 344/02, 14 October 2002, p.4, available at: http://register.consilium.eu.int/pdf/en/02/cv00/ 00344en2.pdf. Also Rashbrooke, 22 Journal of Energy and Natural Resources Law (2004) 373 at 377-8; Trüe, 59 Juristenzeitung (2004) 779 at 786-7. 